\title{
PENGARUH PIUTANG DAN UKURAN PERUSAHAAN TERHADAP SALES GROWTH
}

\author{
Adi Irawan Setiyanto ${ }^{1}$, Nurzilla ${ }^{2}$ \\ Program Studi Akuntansi Manajerial \\ Politeknik Negeri Batam \\ Jl. Ahmad Yani, Batam Centre, Batam 29461, Indonesia \\ E-mail: Adiirawan@polibatam.ac.id
}

\begin{abstract}
Abstrak
Penelitian ini bertujuan untuk memperoleh bukti empiris mengenai beberapa faktor yang mempengaruhi sales growth perusahaan yaitu pengaruh piutang, umur perusahaan dan ukuran perusahaan terhadap Sales Growth perusahaan pada perusahaan manufaktur sektor barang konsumsi yang terdaftar di Bursa Efek Indonesia (BEI) periode tahun 2012-2016. Variabel dependen sales growth diukur dengan proksi jumlah penjualan perusahaan. Variabel Independen Piutang diukur dengan nilai account receivable perusahaan, variabel umur perusahaan diukur dengan umur sejak perusahaan berdiri dan variabel ukuran perusahaan diukur dengan total aset yang dimiliki perusahaan. Metode penelitian ini menggunakan pendekatan metode kuantitatif. Sampel penelitian dipilih menggunakan metode purposive sampling dengan kriteria tertentu dan diperoleh sebanyak 140 sampel perusahaan manufaktur yang memenuhi memenuhi kriteria. Teknik analisis data yang digunakan adalah analisis regresi data panel. Hasil penelitian ini menunjukkan bahwa piutang \& ukuran perusahaan berpengaruh terhadap sales growth perusahaan. Sedangkan usia perusahaan tidak mempengaruhi sales growth perusahaan.
\end{abstract}

Kata kunci: Piutang, Ukuran Perusahaan, Umur perusahaan, dan Sales Growth

\begin{abstract}
This study aims to obtain empirical evidence of several factors that affect the company's sales growth, namely the influence of Accounts Receivable, Firm Age and Firm Size to Sales Growth of companies in the manufacturing sector of consumer goods listed on the Indonesia Stock Exchange (IDX) period 2012-2016. The dependent variable of sales growth is measured by the proxy of the company's sales amount. Independent Variables Receivables are measured by the firm's receivable account value, the firm's age variable is measured by age since the company stands and the firm size variable is measured by the total assets owned by the company. This research method using approach of quantitative method. The sample was chosen using purposive sampling method with certain criteria and obtained as many as 140 samples of manufacturing companies that meet the criteria. Data analysis technique used is panel data regression analysis. The results of this study indicate that accounts receivable \& firm size affect the company's sales growth. While the age of the company does not affect the company's sales growth.
\end{abstract}

Key Words: Accounts Receivable, Firm Age and Firm Size to Sales Growt 


\section{Pendahuluan}

Pertumbuhan penjualan berpengaruh besar terhadap pertumbuhan perekonomian perusahaan di Indonesia. Industri manufaktur sangat berkontribusi terhadap pertumbuhan perekonomian di Indonesia hal tersebut dikarenakan industri manufaktur merupakan sektor yang paling banyak menyerap tenaga kerja. Pada tahun 2012 laju pertumbuhan sektor manufaktur di Indonesia meningkat semakin cepat itu merupakan hasil dari permintaan domestik terutama untuk permintaan barang konsumsi (www.bps.go.id).

Turunnya tingkat pertumbuhan perekonomian industri manufaktur di Indonesia menunjukkan adanya kesulitan yang menghambat aktivitas perusahaan yang tidak lepas dari proses penjualan produk yang telah dihasilkan. Hutang maupun piutang yang dilakukan perusahaan merupakan kegiatan rutinitas dalam memperlancar penjualan suatu produk. Penjualan yang lancar sangat menentukan keberhasilan perusahaan menjalankan aktivitasnya, untuk mengetahui bagaimana keberhasilan penjualan pada perusahaan dapat dilihat dari sales growth pada setiap perusahaan.

Sales growth dapat didefinisikan sebagai tingkat perkembangan jumlah volume penjualan rata-rata atas produk atau layanan yang dihasilkan oleh perusahaan. Pengukuran sales growth dilihat berdasarkan tahun ke tahun apabila nilai perbandingannya semakin besar maka dapat dikatakan bahwa tingkat sales growth semakin baik. Menurut Barton, et al., (1989) sales growth mencerminkan manifestasi keberhasilan investasi periode masa lalu dan dapat dijadikan sebagai prediksi pertumbuhan masa yang akan datang selain itu sales growth juga merupakan indikator permintaan dan daya saing perusahaan dalam suatu perusahaan.

Perusahaan yang melakukan penjualan untuk sebuah produk maupun jasa dengan baik akan mempunyai piutang (Tampubolon, 2013). Piutang merupakan klaim dalam bentuk uang atau hak yang dimiliki perusahaan terhadap pelanggan yang timbul karena penjualan kredit (Kieso, 2008). Sebuah perusahaan menjadikan piutangnya sebagai investasi aktiva lancar dan diakui sebagai account receivable disisi aktif neraca. Piutang yang diberikan perusahaan merupakan cara untuk menaikkan omset perusahaan. Sebuah negara yang memiliki perusahaan dengan omset terbesar maka pertumbuhan perekonomian suatu negara tersebut pasti meningkat pesat.

Perusahaan yang memberikan piutang kepada pelanggan telah memberikan kesempatan lebih pada pelanggan untuk mendapatkan suatu produk atau jasa dengan mudah. Piutang yang diberikan akan menimbulkan keuntungan tersendiri bagi perusahaan pertama, dengan memberikan kepercayaan kepada pelanggan membuat perusahaan mudah mendapatkan pelanggan baru dan mempertahankan pelanggan lama. Kedua, keuntungan pertama akan menjadi daya tarik pelanggan untuk terus menerus melakukan transaksi pembelian membuat volume penjualan akan menaik mengakibatkan laba perusahaan juga meningkat. Semakin banyak kesempatan yang diberikan perusahaan kepada pelanggan maka semakin besar pula operasional dan peningkatan penjualannya, di sisi lain ada kemungkinan akan terjadinya piutang macet tak tertagih yang akan mengurangi sisi keuntungan perusahaan, sedangkan sales growth adalah perusahaan dengan penjualan yang relatif stabil dapat lebih aman memperoleh lebih banyak pinjaman dan menanggung beban tetap yang lebih tinggi dibandingkan dengan perusahaan yang penjualannya tidak stabil (Weston \& Brigham, 1994).

Faktor ukuran perusahaan memainkan peran penting dalam mendefinisikan pertumbuhan perusahaan. Semakin besar ukuran suatu perusahaan akan menunjukkan perusahaan lebih berkembang sehingga investor akan merespon positif dan kinerja pasar perusahaan akan meningkat (Sujoko \& Subiantoro, 2007). Jika kinerja pasar meningkat maka penjualan yang dilakukan perusahaan akan semakin mudah karena pangsa pasar yang relatif besar akan menunjukkan daya saing tinggi dibandingkan dengan perusahaan pesaing. Umur perusahaan mencerminkan seberapa lama perusahaan dapat bertahan dalam bersaing dan mengambil kesempatan bisnis perekonomian. Menurut Bestivano, Perusahaan yang telah lama berdiri pada dasarnya memiliki profitabilitas yang lebih stabil dibandingkan perusahaan yang baru berdiri atau yang masih memiliki umur singkat.

\section{Teori \\ Teori Kredit Perdagangan}

Kredit perdagangan terjadi ketika pemasok mengirimkan barang atau jasa kepada pelanggan pada $\mathrm{t}=0$ dan memungkinkan pelanggan untuk menunda pembayaran barang selama periode tertentu. Dengan demikian, pelanggan akan membayar barang atau jasa yang telah diberikan di $\mathrm{t}=1$. Gagasan umum yang sejalan melalui beberapa penelitian mengenai penawaran kredit perdagangan adalah bahwa tujuan utama pemberian kredit adalah untuk meningkatkan penjualan (Nadiri, 1969).

Nadiri (1969) adalah orang pertama yang mengembangkan model teori neoklasik di mana perusahaan mempertimbangkan biaya pemberian kredit perdagangan sebagai jenis biaya jual untuk mempengaruhi permintaan produk atau jasa yang 
dihasilkan. Dalam kerangka teoritisnya, perusahaan diasumsikan memilih harga output, biaya pemberian kredit perdagangan (opportunity cost investasi dalam trade credit) dan volume output untuk memaksimalkan laba bersih. Hasil dari Modelnya adalah penyediaan kredit perdagangan secara positif terkait dengan tingkat penjualan juga sebagai margin keuntungan. Studi ini menunjukkan bahwa perusahaan menggunakan kredit perdagangan untuk meningkatkan penjualan dan profitabilitas. Oleh karena itu, perusahaan yang membelanjakan lebih banyak penyediaan kredit perdagangan akan mendapatkan tingkat penjualan dan profitabilitas yang lebih tinggi.

\section{Literatur}

Yazdanfar \& Ohman (2014) melakukan penelitian mengenai hubungan credit supply terhadap sales growth menggunakan sampel 13.548 UKM di negara maju Swedia pada periode 2009-2012. Penelitiannya menggunakan sales growth sebagai variable dependen. Variable independennya menggunakan credit supply yang diukur dengan proxy piutang (account receivable), penelitian ini juga menggunakan variable control yaitu age dan size firm. Hasil dari penelitian ini menunjukkan hubungan positif credit supply terhadap sales growth perusahaan.

Gracia Truel \& Martinez-Solano (2010) melakukan penelitian terhadap 47.197 UKM di Eropa pada periode 1996-2002. Dengan menggunakan metodologi data panel, hasilnya menunjukkan hubungan negatif antara piutang usaha kecil terhadap pertumbuhan penjualan.

\section{Piutang Usaha}

Mulyadi (1997) Menyatakan bahwa dalam transaksi penjualan kredit jika order dari pelanggan telah dipenuhi dengan pengiriman barang atau penyerahan jasa untuk jangka waktu tertentu berarti perusahaan memiliki piutang kepada pelanggannya. Menurut Warren, et al., Piutang usaha (account receivable) timbul akibat adanya penjualan kredit. Sebagian besar perusahaan melakukan penjualan banyak terhadap produk atau jasa yang dihasilkan yaitu dengan cara kredit. Semakin banyak produk atau jasa yang dijual maka semakin besar pula peningkatan volume penjualan pada perusahaan.

Peneliti menetapkan variabel independen utama adalah piutang perdagangan diukur sebagai account receivable yang dapat dipulihkan di neraca keuangan. Maka peneliti mengambil simpulan hipotesis pertama yaitu sebagai berikut:

H1: Piutang Berpengaruh Terhadap Sales Growth Perusahaan Manufaktur Di Indonesia.

\section{Ukuran Perusahaan}

Menurut Jermias (2008) perusahaan yang lebih besar cenderung untuk mengambil keuntungan dari skala ekonomi dan memiliki pangsa pasar yang lebih besar serta kemampuan yang lebih baik untuk menggunakan teknologi dan diversifikasi produk dari pada perusaahaan kecil. Kelebihan yang dimiliki membuat perusahaan besar lebih berani dalam memenangkan persaingan atau bertahan dalam dunia industri sehingga perusahaan dengan ukuran yang lebih besar akan mudah menjalankan operasional perusahaan dan menaikkan tingkat penjualan produk yang dihasilkan. Untuk itu, hipotesis kedua adalah sebagai berikut:

H2: Ukuran Perusahaan Berpengaruh Terhadap Sales Growth Perusahaan Manufaktur Di Indonesia.

\section{Umur Perusahaan}

Berdasarkan keterkaitan dengan tujuan keuangan dalam siklus hidup perusahaan secara eksplisit bahwa tujuan jangka panjang perusahaan adalah investor dan meningkatkan kinerja perusahaan (Kaplan \& Norton, 1996). Umur perusahaan mencerminkan perusahaan tetap bertahan. Lamanya perusahaan berdiri menunjukkan bahwa perusahaan mampu memenangkan kesempatan bisnis yang ada dalam perekonomian. Das (1995) \& Jovanovic (1982) menemukan dampak positif usia perusahaan terhadap pertumbuhan perusahaan. Hasil yang berbeda ditemukan oleh Becchetti dan Travato yang mengidentifikasi hubungan negatif antara umur perusahaan dan pertumbuhan perusahaan.

H3: Umur Perusahaan berpengaruh terhadap Sales Growth perusahaan manufaktur di Indonesia. Berikut gambaran kerangka pemikiran pada penelitian ini:

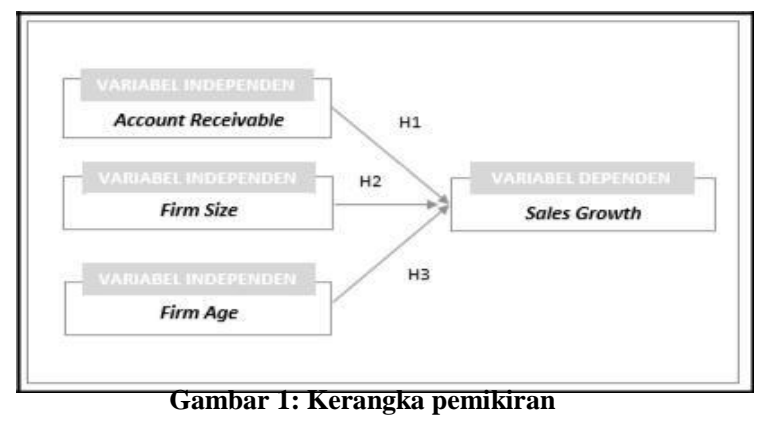

3. Metode Penelitian

\section{Jenis dan Sumber Data}

Hipotesis Pendekatan metode yang digunakan dalam penelitian ini adalah dalam bentuk kuantitatif dimana penelitian ini menggunakan data sekunder. Data pada penelitian ini diambil dari laporan keuangan perusahaan yang terdaftar di Bursa Efek Indonesia pada tahun 2012-2016. Variabel dependen penelitian ini adalah sales growth. Variabel independen yang digunakan dalam penelitian ini adalah piutang 
perusahaan (account receivable), ukuran perusahaan (firm size), dan umur perusahaan (firm age).

\section{Operasional Variabel dan Pengukuran}

Menurut Sugiyono, Variabel adalah suatu atribut, sifat, objek, atau kegiatan yang mempunyai variasi tertentu yang ditetapkan oleh peneliti untuk dipelajari dan ditarik kesimpulan. Pada bagian ini akan dijelaskan mengenai definisi dari setiap variabel yang digunakan didalam penelitian ini, yaitu mencakup variabel independen, variabel dependen, dan variabel kontrol. Definisi operasional variabel ini ditentukan berdasarkan kerangka konseptual, tujuan, dan hipotesis penelitian.

\section{Variabel Independen}

Berdasarkan studi empiris yang telah dilakukan sebelumnya oleh Niskanen \& Niskanen (2006), variabel independen dalam penelitian ini adalah piutang (account receivable) yang akan diukur sebagai akun yang dapat dipulihkan di neraca. Menurut Weston \& Brigham (1991) piutang merupakan kredit jangka pendek terbesar bagi setiap perusahaan, dimana jumlahnya dapat mencapai 40 persen dari keseluruhan hutang lancar pada perusahaan non lembaga keuangan. Ukuran perusahaan yang akan diukur dengan logaritma alami total asset perusahaan dan umur perusahaan akan diukur dengan logaritma alami dari tahun sejak berdirinya perusahaan.

\section{Variabel Dependen}

Variabel dependen dalam penelitian ini adalah sales growth yang didefinisikan sebagai persentase perubahan penjualan per periode, sebuah ukuran dari penelitian yang dilakukan sebelumnya oleh Gracia\& Martinez (2010); Niskanen \& Niskanen (2006). Pertumbuhan penjualan akan diukur berdasarkan perubahan penjualan pada laporan keuangan per periode. Menurut Swastha \& Handoko, pertumbuhan atas penjualan merupakan indikator penting dari penerimaan pasar atas produk atau jasa perusahaan tersebut, dimana pendapatan yang dihasilkan dari penjualan akan dapat digunakan untuk mengukur tingkat pertumbuhan penjualan.

$$
\text { TABEL } 1 .
$$

PENGUKURAN VARIABEL

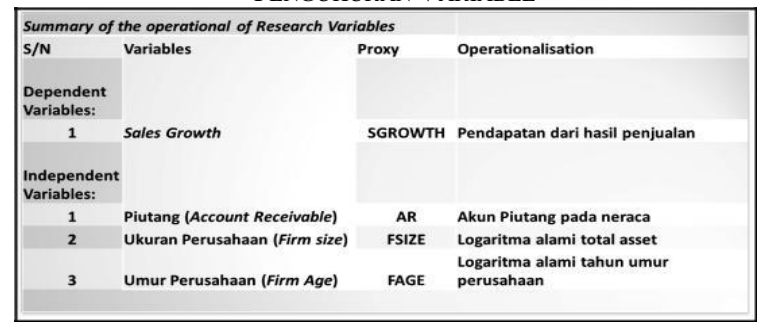

\section{Lokasi dan Obyek Penelitian}

Obyek yang digunakan dalam penelitian ini adalah laporan keuangan yang diterbitkan oleh perusahaan manufaktur yang terdaftar di Bursa Efek Indonesia. Data diambil melalui situs resmi BEI (www.idx.co.id). Populasi dalam penelitian ini terdiri dari perusahaan manufaktur beroperasi disektor industri barang konsumsi yang listing di BEI pada tahun 2012-2016.

\section{Teknik Penetapan Jumlah Sampel}

Teknik penetapan jumlah sampel pada penelitian ini menggunakan model purposive sampling. Sampel yang digunakan dalam penelitian ini merupakan sampel yang memenuhi kriteria penentuan sampel. Jumlah sampel yang diambil adalah sebanyak 40 perusahaan manufaktur sektor barang konsumsi yang terdaftar di BEI.

\section{Teknik Penarikan Sampel}

Populasi yang digunakan dalam penelitian ini adalah perusahaan manufaktur sektor barang konsumsi yang terdaftar di Bursa Efek Indonesia. Penarikan sampel (Sampling) dilakukan secara non probability sampling yaitu dengan purposive sampling. Sampel yang digunakan adalah sampel yang memenuhi kriteria yang ditetapkan penulis, yaitu sebagai berikut:

1. Perusahaan maufaktur yang listing terdaftar di Bursa Efek Indonesia (BEI) selama periode 2012-2016.

2. Data yang tersedia lengkap (kelengkapan secara keseluruhan tersedia pada publikasi periode 2012-2016) baik data mengenai piutang perusahaan maupun data yang diperlukan untuk mendeteksi pertumbuhan penjualan.

TABEL 2.

TOTAL KESELURUHAN DATA

\begin{tabular}{|lccccc|}
\hline \multirow{2}{*}{ Deskripsi Data } & \multicolumn{5}{c|}{ Tahun Observasi } \\
\cline { 2 - 7 } & $\mathbf{2 0 1 2}$ & $\mathbf{2 0 1 3}$ & $\mathbf{2 0 1 4}$ & $\mathbf{2 0 1 5}$ & $\mathbf{2 0 1 6}$ \\
\hline Perusahaan Manufaktur Sektor Barang Konsumsi 2012 & -2016 & & & \\
\hline$\quad$ Sub Sektor Makanan \& Minuman & 16 & $\mathbf{1 6}$ & 16 & $\mathbf{1 4}$ & 14 \\
\hline Sub Sektor Rokok & 4 & 4 & 4 & 4 & $\mathbf{4}$ \\
\hline Sub Sektor Farmasi & 9 & $\mathbf{1 0}$ & 10 & 10 & 10 \\
\hline $\begin{array}{l}\text { Sub Sektor Kosmetik \& Barang Keperluan } \\
\text { Rumah Tangga }\end{array}$ & 4 & 4 & 4 & $\mathbf{6}$ & 6 \\
\hline$\quad$ Sub Sektor Peralatan Rumah Tangga & 3 & $\mathbf{3}$ & $\mathbf{4}$ & 3 & $\mathbf{3}$ \\
\hline Total & $\mathbf{3 6}$ & $\mathbf{3 7}$ & $\mathbf{3 8}$ & $\mathbf{3 7}$ & $\mathbf{3 7}$ \\
\hline Perusahaan IPO/ Delisting/ Change sub & $(0)$ & $(1)$ & $(1)$ & $(2)$ & $(0)$ \\
\hline Data yang outlier & $(5)$ & $(5)$ & $(5)$ & $(5)$ & $(5)$ \\
\hline Jumlah laporan yang tidak lengkap 2012-2016 & $(3)$ & $(3)$ & $(5)$ & $(2)$ & $(\mathbf{4})$ \\
\hline Total data & $\mathbf{2 8}$ & $\mathbf{2 8}$ & $\mathbf{2 8}$ & $\mathbf{2 8}$ & $\mathbf{2 8}$ \\
\hline Total akhir data yang diperoleh & & & $\mathbf{1 4 0}$ & & \\
\hline
\end{tabular}

Sumber: data mentah diolah

\section{Teknik Pengumpulan Data}

Data yang digunakan dalam penelitian ini adalah data sekunder. Pengumpulan data dilakukan dengan mengunduh laporan keuangan, kemudian ditabulasikan ke microsoft excel. Pengumpulan data 
dilakukan dengan melakukan pemisahan untuk penghitungan jumlah sampel yang tidak sesuai dengan kategori sampel.

\section{Teknik Pengolahan Data}

Penelitian ini melakukan pengolahan data melalui tiga tahap, yaitu coding, tabulasi data, dan pengolahan data menggunakan program EViews versi 9.0 Tahap coding dilakukan dengan memberikan kode angka pada variabel independen sebagai pembeda. Tabulasi data dilakukan dengan merekap data melalui angka yang diperoleh dari laporan keuangan auditan tahun 2012-2016 menggunakan microsoft excel. Tahapan terakhir dalam penelitian ini adalah pengolahan data menggunakan program EViews versi 9.

\section{Teknik Analisis Data}

Analisis data ini digunakan untuk mengetahui gambaran secara umum data penelitian mengenai variabel penelitian yaitu piutang, ukuran perusahaan dan umur perusahaan dan sales growth. Analisis data yang digunakan dalam penelitian ini adalah analisis regresi data panel. Data panel merupakan data gabungan antara data time series dan cross section (Winarno, 2009). Data yang diperoleh dalam penelitian ini diolah dengan menggunakan:

\section{Model regresi data panel}

\section{a. Model Efek Sederhana (Common}

\section{Effect)}

Model efek sederhana bertujuan untuk memperhatikan dimensi individu maupun waktu sehingga diasumsikan bahwa perilaku antar individu sama dalam berbagi kurun waktu. Model ini hanya mengkombinasikan data time series dan cross section dalam bentuk pool, mengestimasinya menggunakan pendekatan kuadrat terkecil atau pooled least square (Nachrowi, 2006).

\section{b. Model Efek Tetap (fixed effect)}

Model efek tetap bertujuan untuk mengasumsikan perbedaan yang terjadi antar individu (Nachrowi, 2006). Setiap parameter yang tidak diketahui dalam model efek tetap akan diestimasi dengan menggunakan teknik variabel dummy.

\section{c. Model Efek Random (Random Effect)}

Model efek random bertujuan untuk mengestimasi bahwa ada perbedaan intersep untuk setiap individu dan intersep tersebut merupakan variabel random (Nachrowi, 2006).

\section{Pemilihan model regresi data panel a. Uji Chow (Chow Test)}

Uji chow bertujuan untuk membandingkan atau memilih model mana yang terbaik antara common effect dan fixed effect. Penentuan model harus memperhatikan nilai probabilitas (Prob) untuk crosssection $\mathrm{F}$ jika nilainya $>0.05$ maka model yang terpilih adalah common effect, tetapi jika $<0.05$ maka model yang terpilih adalah fixed effect.

\section{b. Uji Hausman (Hausman Test)}

Uji hausman bertujuan untuk membandingkan atau memilih model mana yang terbaik antara fixed effect dan random effect. Penentuan model harus memperhatikan nilai probabilitas (Prob.) untuk crosssectionrandom. Jika nilainya $>0.05$ maka model yang terpilih adalah random effect, tetapi jika $<0.05$ maka model yang terpilih adalah fixed effect.

\section{c. Uji Langrangge Multiple (LM Test)}

Uji langrangge multiple bertujuan untuk membandingkan atau memilih model mana yang terbaik antara common effect dan random effect. Penentuan model harus membandingkan nilai LMhitung dengna Chi Squaredtabel dengan alpa 5\%. Jika nilai LMhitung>Chi Squaredtabel maka model yang dipilih adalah random effect, sebaliknya jika nilai LMhitung $<$ Chi Squaredtabel maka model yang dipilih adalah common effect.

\section{Pengujian Hipotesis}

Uji hipotesis (t-test) atau dikenal uji parsial digunakan untuk mengetahui pengaruh masingmasing variabel independen terhadap variabel dependen. Uji t statistika ini menunjukkan seberapa jauh pengaruh satu varibel independen secara individual dalam menerangkan variasi variabel dependen. Penerapan uji t statistika ini didasarkan pada hipotesis nol (Ho) yang akan diuji dan hipotesis alternatif (Ha) (Ghozali, 2011).

\section{Pembahasan}

\section{Analisis Deskriptif}

Statistik deskriptif dilakukan dengan tujuan untuk memberikan gambaran tentang suatu data yang dilihat dari nilai minimum, maksimum, rata- rata (mean), dan standar deviasi yang dihasilkan dari variabel penelitian. Hasil analisis statistik deskriptif dengan menggunakan program EViews 9.0 yang terdapat dalam tabel berikut:

TABEL 3.

HASIL ANALISIS STATISTIK

\begin{tabular}{ccccc}
\hline & SGROWTH & ARECEIVABLE & LNFSIZE & LNFAGE \\
\hline Mean & 0.0979 & 9.8633 & 28.1630 & 3.6492 \\
Median & 0.0988 & 8.4329 & 27.8851 & 3.7136 \\
Maximum & 0.5785 & 45.3917 & 32.1510 & 4.4659 \\
Minimum & -0.4657 & 1.5407 & 25.2767 & 2.7081 \\
Std. Dev. & 0.15977039 & 7.819406642 & 1.537538988 & 0.3722025 \\
\hline \multicolumn{5}{c}{ Sumber: Dota yang diolah dengan EViews 9.0}
\end{tabular}

Total sampel yang sesuai dengan kriteria sampel penulis berjumlah 140 perusahaan. Dari jumlah 
tersebut, maka sebesar 10 perusahaan dihilangkan sebagai sampel karena berada di luar tiga deviasi standar dari rata-rata variabel penelitian atau dikatakan data outlier. Penelitian ini menguji variabel dependen yaitu sales growth yang diukur dengan nilai penjualan setiap tahun menunjukkan nilai ratarata (mean) sebesar 0.097 yang menggambarkan bahwa pada periode tahun 2012-2016 perusahaan manufaktur sektor barang konsumsi diIndonesia mengalami rata-rata pertumbuhan penjualan sebesar $0.97 \%$. Nilai tertinggi (maksimum) sebesar 0.57 dan nilai terendah (minimum) sebesar 0,46 dengan standar deviasi sebesar 0,195. Perusahaan yang memiliki tingkat penjualan tertinggi yaitu perusahaan sub sektor farmasi PT Merck Sharp Dohme Pharma Tbk.

Variabel independen yaitu piutang yang diukur dengan logaritma natural account receivable perusahaan menunjukkan nilai rata- rata sebesar 9,86 yang menggambarkan bahwa pada periode 20122016 tingkat rata-rata ARECEIVABLE adalah 9,86\%. Nilai tertinggi (maksimum) sebesar 45,39 dan nilai terendah (minimum) sebesar 1,54 dengan standar deviasi 7,81. Perusahaan yang memiliki nilai ARECEIVABLE terbesar yaitu perusahaan sub sektor rokok PT Gudang Garam Tbk.

Variabel ukuran perusahaan yang diukur dengan logaritma natural total assets perusahaan menunjukkan nilai rata- rata sebesar 28,16 yang menggambarkan rata- rata ukuran perusahaan manufaktur sektor barang konsumsi di Indonesia sebesar $28,16 \%$. Nilai tertinggi (maksimum) sebesar 32,15 dan nilai terendah (minimum) sebesar 25,27 dengan standar deviasi 1,53. Perusahaan yang memiliki tingkat ukuran terbesar yaitu PTIndofood Sukses Makmur Tbk.

Variabel umur perusahaan yang diukur dengan logaritma natural umur sejak berdirinya perusahaanmenunjukkan nilai rata-rata sebesar 3,64 yang menggambarkan rata-rata umur perusahaan manufaktur sektor barang konsumsi di Indonesia sebesar 3,64\%. Nilai tertinggi (maksimum) sebesar 4,46 dan nilai terendah (minimum) sebesar 2,70 dengan standar deviasi 0,37. Perusahaan yang memiliki umur terlama yaitu PT Multi Bintang Indonesia Tbk berumur 87 tahun.

\section{Uji Model EViews \\ a) Uji Chow (F test)}

Uji chow dilakukan untuk membandingkan atau memilih model regresi mana yang terbaik antara common effect dan fixed effect, dimana tingkat signifikasi sebesar 0,05. Berikut hasil pengujian Chisquare (chow test) dapat dilihat pada table sebagai berikut:

\begin{tabular}{ccccc}
\multicolumn{6}{c}{ TABEL 4. } \\
UJI CHOW \\
\hline Hipotesis & Effect Test & Statistic & d.f & Prob. \\
\hline \multirow{2}{*}{ H1 } & Cross-section Chi-square & 44.246606 & 27 & 0.0195 \\
H2 & Cross-section|Chi-square & 36.007303 & 27 & 0.1151 \\
H3 & Cross-section Chi-square & 46.033747 & 27 & 0.0126 \\
\hline \multicolumn{6}{c}{ Sumber: Output Olahan EViews 9.0 }
\end{tabular}

Besarnya probabilitas Cross-section Chi-square pada H1 adalah sebesar 0,0195. Nilai probabilitas Crosssection Chi-square tersebut $<0,05$. Hasil tersebut menunjukkan bahwa lebih tepat menggunakan model fixed effect dibandingkan dengan model common effect, maka selanjutnya akan dilakukan uji hausman.

Probabilitas Cross-section Chi-square pada H2 adalah sebesar 0.1151. Nilai probabilitas Crosssection Chi-square tersebut >0,05. Hasil dari uji chow tersebut menunjukkan bahwa lebih tepat menggunakan model common effect dibandingkan dengan model fixed effect.

Probabilitas Cross-section Chi-square pada H3 adalah sebesar 0.0126. Nilai probabilitas Crosssection Chi-square tersebut $<0,05$. Hasil dari uji chow tersebut menunjukkan bahwa lebih tepat menggunakan model fixed effect dibandingkan dengan model common effect, maka selanjutnya akan dilakukan uji hausman.

\section{b) Uji Hausman}

Metode Uji Hausman dilakukan untuk membandingkan atau memilih model mana yang terbaik antara fixed effect dan random effect, dimana tingkat signifikansi sebesar 0,05. Berikut hasil uji hausman dapat dilihat pada table, sebagai berikut:

TABEL 5.

UJI HAUSMAN

\begin{tabular}{ccccc}
\hline Hipotesis & Test Summary & Chi-Sq.Statistic & $\begin{array}{c}\text { Chi-Sq. } \\
\text { d.f. }\end{array}$ & Prob. \\
\hline H1 & Cross-section Random & 7.564951 & 1 & 0.006 \\
H3 & Cross-section Random & 8.878571 & 2 & 0.0029 \\
\hline \multicolumn{5}{c}{ Sumber: Output Olahan EViews 9.0}
\end{tabular}

Berdasarkan tabel di atas besarnya probabilitas crosssection random pada $\mathrm{H} 1$ adalah sebesar 0,006. Nilai probabilitas cross-section random tersebut $<0,05$, maka hasil hausman test menunjukkan bahwa model fixed effect lebih tepat digunakan untuk model persamaan regresi pada hipotesis 1 .

Besarnya probabilitas cross-section random pada $\mathrm{H} 3$ adalah sebesar 0.0029. Nilai probabilitas crosssection random tersebut $<0,05$, maka hasil hausman test menunjukkan bahwa model fixed effect lebih 
tepat digunakan untuk model persamaan regresi pada hipotesis 3.

\section{Uji Asumsi Klasik}

\section{a) Uji Multikolinearitas}

Berdasarkan hasil output table dibawah terlihat tidak adanya masalah multikolinearitas antara variabel independen karena nilai setiap variabel lebih kecil dari 0,8 (correlation $<0,8$ ).

TABEL 6.

UJI MULTIKOLINEARITAS

\begin{tabular}{lrrrrr}
\hline & ARECEIVABLE & LNFAGE & LNFSIZE & & \multicolumn{1}{c}{ SGROWTH } \\
\hline ARECEIVABLE & 1,00 & 0,58 & 0,49 & 0,09 \\
LNFAGE & 0,58 & 1,00 & 0,80 & $-0,27$ \\
LNFSIZE & 0,49 & 0,80 & 1,00 & $-0,44$ \\
SGROWTH & 0,09 & $-0,27$ & $-0,44$ & 1,00 \\
\hline \multicolumn{5}{c}{ Sumber: Output Olahan EViews 9.0} \\
\hline
\end{tabular}

\section{b) Uji Heteroskedastisitas}

1) Piutang berpengaruh terhadap Sales Growth perusahaan manufaktur di Indonesia.

Nilai Obs *R-Squared adalah 2,304504 sedangkan nilai probabilitas adalah $0,3159>0,05$ maka dapat disimpulkan bahwa data tidak mengalami masalah heteroskedastisitas.

TABEL 7

UJI HETEROKEDASTISITAS (H1)

\begin{tabular}{lllr}
\hline \multicolumn{4}{l}{ Heteroskedasticity Test: White } \\
\hline & & & \\
F-statistic & 0,981581 & Prob. F(2,4) & 0,45 \\
Obs* R-squared & 2,304504 & Prob. Chi-Square(2) & 0,3159 \\
Scaled explained SS & 2,234097 & Prob. Chi-Square(2) & 0,3272 \\
\hline \multicolumn{4}{c}{ Sumber: Output Olahan EViews 9.0 }
\end{tabular}

\section{2) Ukuran Perusahaan berpengaruh terhadap Sales Growth perusahaan manufaktur di Indonesia.}

Nilai Obs *R-Squared adalah 3,73469 sedangkan nilai probabilitas adalah $0,1545>0,05$ maka dapat disimpulkan bahwa data tidak mengalami masalah heteroskedastisitas.

TABEL 8.

UJI HETEROKEDASTISITAS (H2)

\begin{tabular}{llll}
\hline \multicolumn{4}{l}{ Heteroskedasticity Test: White } \\
\hline & & & \\
F-statistic & 2,287503 & Prob. F(2,4) & 0,2176 \\
Obs ${ }^{*}$ - -squared & 3,734696 & Prob. Chi-Square(2) & 0,1545 \\
Scaled explained SS & 0,685982 & Prob. Chi-Square(2) & 0,7096 \\
\hline \multicolumn{4}{l}{ Sumber: Output Olahan EViews 9.0 }
\end{tabular}

\section{3) Umur Perusahaan berpengaruh terhadap Sales Growth perusahaan manufaktur di Indonesia.}

Nilai Obs *R-Squared adalah 3,73469 sedangkan nilai probabilitas adalah $0,1545>0,05$ menunjukkan data tidak mengalami masalah heteroskedastisitas.

TABEL 9.

UJI HETEROKEDASTISITAS (H3)

\begin{tabular}{|c|c|c|c|}
\hline \multicolumn{4}{|c|}{ Heteroskedasticity Test: White } \\
\hline F-statistic & 2,043074 & Prob. $F(2,4)$ & 0,2447 \\
\hline Obs*R-squared & 3,537289 & Prob. Chi-Square(2) & 0,1706 \\
\hline $\begin{array}{l}\text { Scaled explained } \\
\text { ss }\end{array}$ & 0,719118 & Prob. Chi-Square(2) & 0,698 \\
\hline
\end{tabular}

\section{Uji Hipotesis}

\section{Piutang berpengaruh terhadap Sales Growth perusahaan manufaktur di Indonesia (H1)}

Berdasarkan pengujian EViews untuk menentukan model regresi yang tepat menggunakan uji chow dan uji hausman. Model regresi yang baik digunakan pada hipotesis 1 ini adalah fixed effect. Output regresi yang digunakan dapat dilihat pada tabel berikut:

TABEL 10.

UJI HIPOTESIS (H1)

\begin{tabular}{lrrrr}
\hline Variable & Coefficient & Std. Error & t-Statistic & \multicolumn{1}{l}{ Prob. } \\
\hline C & $-0,138745$ & 0,07888 & $-1,75887$ & 0,0814 \\
ARECEIVEBLE & 0,023997 & 0,00789 & 3,04083 & 0,0029 \\
& & & \\
R-squared & 0,283079 & Mean dependent var & 0,097949 \\
Adjusted R-squared & 0,102234 & S.D. dependent var & 0,159773 \\
S.E. of regression & 0,151386 & Akaike info criterion & $-0,7558$ \\
Sum squared resid & 2,54386 & Schwarz criterion & $-0,14646$ \\
Log likelihood & 81,90578 & Hannan-Quinn criter. & $-0,50818$ \\
F-statistic & 1,565314 & Durbin-Watson stat & 2,467969 \\
Prob(F-statistic) & 0,053045 & \\
\hline \multicolumn{4}{c}{ Sumber: Hasil olah dato program EViews 9.0} \\
\hline
\end{tabular}

Berdasarkan hasil output pada tabel diatas, maka dapat dibuat model persamaan regresi sebagai berikut:

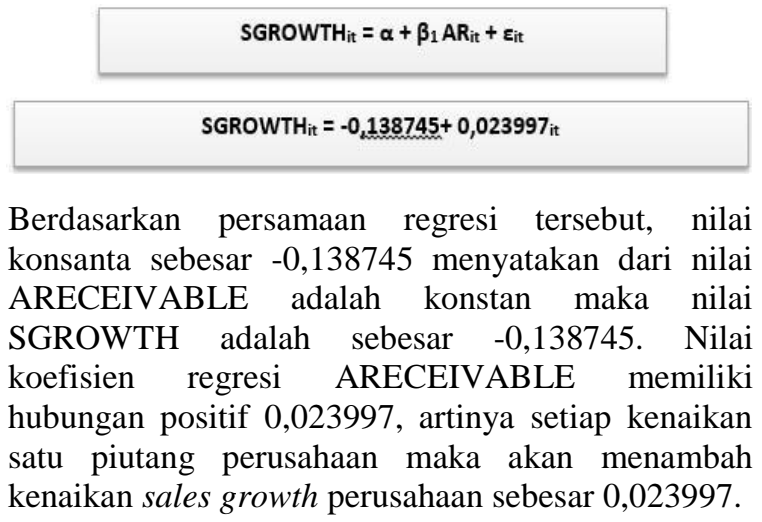


Hasil model fixed effect menunjukkan bahwa nilai koefisien regresi variabel ARECEIVABLE sebesar 0,023997 dengan nilai $t$ sebesar 3,04083 dan signifikansi $0,0029<0,05$, hal ini menunjukkan pengaruh ARECEIVABLE terhadap SGROWTH positif dan signifikan. Nilai R-square sebesar 0,28 atau 28\% mengidentifikasi bahwa variabel ARECEIVABLE mampu menjelaskan variabel terikatnya sebesar $28 \%$ sedangkan sisanya $72 \%$ dapat dijelaskan oleh variabel lain yang tidak termasuk ke dalam model.

\section{Ukuran Perusahaan berpengaruh terhadap Sales Growth perusahaan manufaktur di Indonesia (H2)}

Berdasarkan pengujian EViews untuk menentukan model regresi yang tepat menggunakan Uji Chow pada hipotesis 2 ini adalah Common Effect. Output regresi yang digunakan dapat dilihat pada tabel sebagai berikut:

TABEL 11.

UJI HIPOTESIS (H2)

\begin{tabular}{lrrrr}
\hline Variable & Coefficient & Std. Error & t-Statistic & Prob. \\
\hline C & $-0,075487$ & 0,24906 & $-0,303095$ & 0,7623 \\
LNFSIZE & 0,006158 & 0,00883 & 0,697406 & 0,4867 \\
& & & & \\
R-squared & 0,003512 & Mean dependent var & 0,097949 \\
Adjusted R-squared & $-0,003709$ & S.D. dependent var & 0,159773 \\
S.E. of regression & 0,160069 & Akaike info criterion & $-0,81224$ \\
Sum squared resid & 3,535852 & Schwarz criterion & $-0,77022$ \\
Log likelihood & 58,85678 & Hannan-Quinn criter. & $-0,79516$ \\
F-statistic & 0,486374 & Durbin-Watson stat & 2,022104 \\
Prob(F-statistic) & 0,486722 & & \\
\hline \multicolumn{4}{c}{ Sumber: Hasil olah data program EViews 9.0} \\
\end{tabular}

Berdasarkan hasil output pada tabel diatas, maka dapat dibuat model persamaan regresi sebagai berikut:

SGROWTHit $=\alpha+\beta 2$ FSIZE $_{i t}+\varepsilon_{i t}$

SGROWTHit $=-0,075487+0,006158_{\text {it }}$

Berdasarkan persamaan regresi tersebut dapat dianalisis pengaruh variabel independen terhadap variabel dependen sebagai berikut: nilai konsanta sebesar -0,075487 menyatakan dari nilai LNFSIZE adalah konstan maka nilai SGROWTH adalah sebesar -0,075487. Nilai koefisien regresi LNFSIZE memiliki hubungan positif 0,006158 , artinya setiap kenaikan satu asset perusahaan maka akan menambah kenaikan sales growth perusahaan sebesar 0,006158.

Hasil model common effect menunjukkan bahwa nilai koefisien regresi variabel LNFSIZE sebesar 0,006158 dengan nilai $\mathrm{t}$ sebesar 0,697406 dan signifikansi $0,4867>0,05$, hal ini menunjukkan pengaruh LNFSIZE terhadap SGROWTH positif dan tidak signifikan. Nilai R-square sebesar 0,035 atau
$0.35 \%$ mengidentifikasi bahwa variabel LNFSIZE mampu menjelaskan variabel terikatnya sebesar $0.35 \%$ sedangkan sisanya $99.65 \%$ dapat dijelaskan oleh variabel lain yang tidak termasuk ke dalam model.

\section{Ukuran Perusahaan berpengaruh terhadap Sales Growth perusahaan manufaktur di Indonesia}

Berdasarkan pengujian EViews untuk menentukan model regresi yang tepat menggunakan Uji Chow dan Uji Hausman, model regresi yang baik digunakan pada hipotesis 3 ini adalah fixed Effect. Output regresi yang digunakan dapat dilihat pada tabel sebagai berikut:

TABEL 12 UJI HIPOTESIS (H3)

\begin{tabular}{lrrrr}
\hline Variable & Coefficient & Std. Error & t-Statistic & Prob. \\
\hline C & 3,456682 & 1,0928 & 3,163151 & 0,002 \\
LNFAGE & $-0,920403$ & 0,29944 & $-3,07373$ & 0,0027 \\
& & & \\
R-squared & 0,284276 & Mean dependent var & 0,097949 \\
Adjusted $R$-squared & 0,103734 & S.D. dependent var & 0,159773 \\
S.E. of regression & 0,151259 & Akaike info criterion & $-0,75747$ \\
Sum squared resid & 2,539612 & Schwarz criterion & $-0,14813$ \\
Log likelihood & 82,02279 & Hannan-Quinn criter. & $-0,50985$ \\
F-statistic & 1,574565 & Durbin-Watson stat & 2,797738 \\
Prob(F-statistic) & 0,050782 & & \\
\hline \multicolumn{4}{c}{ Sumber: Hasil olah dato program EViews 9.0} \\
\end{tabular}

Berdasarkan hasil output pada tabel diatas, maka dapat dibuat model persamaan regresi sebagai berikut:

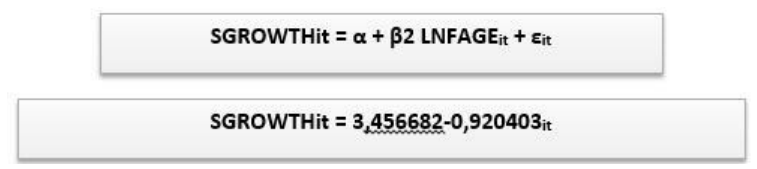

Berdasarkan persamaan regresi tersebut dapat dianalisis pengaruh variabel independen terhadap variabel dependen sebagai berikut: nilai konsanta sebesar 3,456682 menyatakan dari nilai LNFAGE adalah konstan maka nilai SGROWTH adalah sebesar 3,456682. Nilai koefisien regresi LNFAGE memiliki hubungan negatif $-0,920403$, artinya setiap kenaikan satu tahun umur perusahaan maka akan mengurangi sales growth perusahaan sebesar 0,920403 .

Hasil model fixed effect menunjukkan bahwa nilai koefisien regresi variabel LNFAGE sebesar 0,920403dengan nilai $\mathrm{t}$ sebesar $-3,07373$ dan signifikansi $0,0027<0,05$, hal ini menunjukkan pengaruh LNFAGE terhadap SGROWTH negatif dan signifikan. Nilai R-square sebesar 0,28 atau $28 \%$ mengidentifikasi bahwa variabel LNFAGE mampu menjelaskan variabel terikatnya sebesar $28 \%$ sedangkan sisanya $72 \%$ dapat dijelaskan oleh variabel lain yang tidak termasuk ke dalam model. 


\section{Analisis Data}

Berikut adalah tabel ringkasan hasil uji hipotesis penelitian pada perusahaan manufaktur sektor konsumsi yang terdaftar di Bursa Efek Indonesia periode tahun 2012-2016.

TABEL 13.

RINGKASAN UJI HIPOTESIS

\begin{tabular}{cccc}
\hline No. & Hipotesis & Sig. & Kesimpulan \\
\hline 1. & H1 & 0,0029 & Hipotesis terdukung \\
2. & H2a & 0,4867 & Hipotesis tidak terdukung \\
3. & H2b & 0,0027 & Hipotesis terdukung \\
\hline & & & signifikan pada level $5 \%(\alpha=0.05)$
\end{tabular}

\section{Piutang berpengaruh terhadap Sales Growth perusahaan manufaktur di Indonesia.}

Berdasarkan hasil uji hipotesis ARECEIVABLE (Account Receivable) terhadap SGROWTH (Sales Growth) menunjukkan bahwa H1 terdukung, artinya piutang perusahaan berpengaruh terhadap sales growth. Hasil penelitian ini sama dengan penelitian yang dilakukan oleh Yazdanfar \& Ohman (2014) yang menunjukkan pengaruh positif credit supply (Account Receivable) terhadap sales growth perusahaan. Pengaruh tersebut mengungkapkan bahwa tingkat kemampuan perusahaan dalam melakukan penjualan secara kredit akan mempengaruhi pertumbuhan sales growth perusahaan tersebut. Hasil penelitian ini berbeda dengan penelitian yang dilakukan oleh Gracia Truel \& Martinez Solano (2010) yang menyatakan bahwa piutang usaha berpengaruh negatif terhadap sales growth perusahaan yang berarti ketika perusahaan melakukan lebih banyak penjualan secara kredit maka ketidakstabilan penjualan akan terjadi yang menyebabkan perusahaan dalam kondisi yang tidak aman (Weston \& Brigham, 2004).

\section{Ukuran Perusahaan berpengaruh terhadap Sales Growth perusahaan manufaktur di Indonesia}

Berdasarkan hasil uji hipotesis FSIZE (Firm Size) terhadap SGROWTH (Sales Growth) menunjukkan bahwa H2 tidak terdukung, artinya ukuran perusahaan tidak berpengaruh terhadap Sales Growth. Hasil penelitian ini sama dengan penelitian yang dilakukan oleh Dunhe \& Huges yang menemukan pengaruh negatif dari ukuran perusahaan terhadap Sales Growth perusahaan manufaktur di Inggris. Tidak adanya pengaruh tersebut menunnjukkan bahwa besar atau tidaknya sebuah perusahaan tidak berpengaruh terhadap tingkat Sales Growth pada perusahaan itu sendiri. Hasil penelitian ini berbeda dengan penelitian yang dilakukan oleh Beck, et al., (2005) yang menemukan pengaruh positif antara Firm Size terhadap Sales Growth.

\section{Umur Perusahaan berpengaruh terhadap Sales Growth perusahaan manufaktur di Indonesia}

Berdasarkan hasil uji hipotesis FAGE (Firm Age) terhadap SGROWTH (Sales Growth) menunjukkan bahwa hipotesis ke 3 terdukung, artinya umur perusahaan berpengaruh terhadap Sales Growth. Hasil penelitian ini berbeda dengan penelitian yang dilakukan oleh Gurgle yang menemukan hasil negatif korelasi antara umur perusahaan terhadap pertumbuhan perusahaan. Hasil penelitian ini sama dengan penelitian Das (1995) \& Jovanovic (1982) yang menemukan dampak positif antara umur perusahaan terhadap Sales Growth. Adanya pengaruh antara umur perusahaan terhadap Sales Growth menunjukkan bahwa lama atau barunya usia perusahaan berdiri maka akan mempengaruhi tingkat sales growth perusahaan.

\section{Simpulan}

\section{Simpulan}

Penelitian ini bertujuan untuk meneliti faktor piutang (account receivable), ukuran perusahaan (firm size) \& umur perusahaan (firm age) berpengaruh terhadap sales growth perusahaan manufaktur sektor barang konsumsi di Indonesia yang terdaftar di Bursa Efek Indonesia (BEI). Berdasarkan hasil penelitian diatas peneliti menarik kesimpulan sebagai berikut:

Hipotesis 1 terdukung (positif dan signifikan), Pengaruh tersebut mengungkapkan bahwa tingkat kemampuan perusahaan dalam melakukan penjualan secara kredit akan mempengaruhi pertumbuhan sales growth perusahaan tersebut. Hipotesis 2 tidak terdukung, tidak ada pengaruh yang menunnjukkan bahwa besar atau tidaknya sebuah perusahaan terhadap tingkat Sales Growth pada perusahaan itu sendiri. Hipotesis 3 terdukung (negatif dan signifikan), Adanya pengaruh antara Umur Perusahaan (Firm Age) terhadap Sales Growth menunjukkan bahwa lama atau barunya usia perusahaan berdiri maka akan mempengaruhi tingkat sales growth perusahaan.

\section{Keterbatasan}

Pada penelitian ini penulis menemukan beberapa keterbatasan yang memungkinkan berpengaruh terhadap penelitian ini. Keterbatasan penelitian ini yaitu peneliti hanya menggunakan sampel perusahaan manufaktur sektor barang konsumsi, dan peneliti hanya mengam bil beberapa faktor yang secara umum mempengaruhi sales growth perusahaan. Peneliti tidak menggunakan keseluruhan data yang bersifat outlier. Diharapkan pada penelitian selanjutnya untuk mengembangkan sampel perusahaan yang akan diteliti serta menambah 
variabel lainnya mempengaruhi sales growth perusahaan.

\section{Implikasi}

Penelitian ini dapat dijadikan bahan referensi atau tambahan informasi untuk penelitian selanjutnya yang meneliti tentang Sales Growth. Penelitian ini juga dapat menjadi referensi bagi manajer dan investor agar nantinya perusahaan dapat mengukur kemampuan perusahaan dalam memenuhi target penjualan perusahaan dimasa mendatang.

\section{Daftar Pustaka}

A. Barton, S. L., Ned, C. H., \& Sirinivasan, S. (1989). An Empirical Test of Stakeholder Theory Prediction of Capital Structure. Journal of Financial Management Assosiation.

B. Beck, T. A.-K. (2005). Financial and Legal Constraints to Growth: Does Firm Size Matter? Journal of Finance, 137-177.

C. Das, S. (1995). Age and Firm Growth in an Infant Industry: The Computer Hadware Industry in India. International Journal of Industrial Organization.

D. Ghozali, I. (2011). Aplikasi Analisis Multivariate dengan Proses SPSS. Semarang: Universitas Diponogoro.

E. Gracia-Teruel, P. J., \& Solano, P. M. (2010). Determinants of trade credit: A comparative study of European SMEs. International Small Business Journal.

F. Jermias, J. (2008). The relative influence of competitive intensity and business strategy on the relationship between financial leverage and performance. The British Accounting Review, 71-86.

G. Jovanovic, B. (1982). Selection and Evolution of Industry. Econometrica, 649-670.

H. Kaplan, R. S., \& Norton, D. P. (1996). Strategic learning \& the balanced scorecard. Strategy \& Leadership, 18-24.

I. Kieso. (2008). Akuntansi Intermediate (12 ed., Vol.1). Jakarta: Erlangga.

J. Mulyadi. (1997). Sistem Akuntansi. Yogyakarta: PT Raja Grafindo Persada.

K. Nachrowi, D. (2006). Pendekatan populer dan praktis Ekonometrika untukanalis ekonomi keuangan. Jakarta: Fakultas Ekonomi Universitas Indonesia.

L. Nadiri, M. I. (1969). The Determinats of Trade Credit in the U.S Total Manufacturing Sector vol. 37. Econometrica, 408-423.
M. Niskanen, J., \& Niskanen, M. (2006). The determinants of corporate trade credit policies in a bank-dominated financial environment: the case of Finnish small firms. European Financial Management, 12, 81-102.

N. Sujoko, \& Subiantoro. (2007). Pengaruh Struktur Kepemilikan Saham, Leverage, Faktor Intern dan Faktor Ekstern Terhadap Nilai Perusahaan (Studi Empirik Pada Perusahaan Manufaktur dan Non-Manufaktur di Bursa Efek Jakarta). Jurnal Manajemen dan Kewirausahaan, 9, 41-48.

O. Tampubolon, M. P. (2013). Manajemen Keuangan (Finance Management). Jakarta: Mitra Wacana Media.

P. Warren, C. S., James, M. R., \& Phillip, E. F. (2006). Pengantar Akuntansi (21 ed., Vol. 1). (F. Aria, Amanugrahani, \& H. Taufik, Trans.) Jakarta: Salemba Empat.

Q. Weston, J., \& Brigham. (1994). Dasar Manajemen Keuangan. Jakarta: Erlangga.

R. Winarno. (2009). Analisis Ekonometrika dan Statistika dengan Eviwes. Yogyakarta: YKPN.

S. Yazdanfar, D; Öhman, P. (2014). The impact of credit supply on sales growth: Swedish evidence. International Journal of Managerial Finance, 329-340. 